\title{
Faktor-Faktor Yang Mempengaruhi Penyerapan Anggaran Belanja Pemerintah Daerah: Proses Pengadaan Barang/Jasa Di Kabupaten Bolaang Mongondow Selatan
}

\author{
ELYPAZ DONALD RERUNG ${ }^{1}$, HERMAN KARAMOY ${ }^{2}$, WINSTON PONTOH ${ }^{3}$ \\ ${ }^{1,2,3}$ Program Magister Akuntansi, Fakultas Ekonomi dan Bisnis Universitas Sam Ratulangi \\ email: donaldrerung@gmail.com ${ }^{1}$, hermankaramoy@yahoo.com ${ }^{2}$,Winston_pontoh@yahoo.com ${ }^{3}$
}

\begin{abstract}
Government spending provides a wide range of services to the community. The most significant component of government spending relates to social security and welfare. It is the capital expenditure in Local Government Budget which is intended to finance development to promote such general welfare of the people. Budget absorption is one of the factors in evaluating Government performance to stimulate economic growth. Local Government revenue and expenditure budgets have significant influences to contribute the growth of regional economy if they are absorbed maximally. Budget absorption for goods and services procurement is generally slow. Additionally, budget realization often accumulates at the end of the year due to various problems in both administrative and technical aspects. This study aims to examine the effect of management commitment, bureaucratic environment, human resource competence and implementation of e-procurement towards budget absorption for goods and services procurement. This is a quantitative research and employed multiple regression analysis. The sample of the research is 63 Government employees whose responsibilities are in the budget and goods and services procurement. They are staff in commitment making, budget executing, authorizing or signing the cash disbursement, procurement working group and expenditure treasurer at 14 SKPD Bolaang Southern Mongondow. The result shows that management commitment, bureaucratic environment, and e-procurement implementation have positive and significant impacts to the budget absorption for goods and services procurements. Human resource competencies do not affect the budget absorption for goods and services procurement. The practical implication of this research suggests policy makers to improve human resources competencies for sufficient budget absorption.
\end{abstract}

Keyword: Budget Absorption, Management Commitment, Bureaucracy Environment, Human Resource Competencies, e-Procurement

Abstrak. Belanja modal dalam struktur APBD merupakan pengeluaran pemerintah yang mencerminkan dukungan pemerintah dalam pembangunan untuk kesejahteraan masyarakat. Pelaksanaan belanja modal tersebut dalam rangka peningkatan pelayanan publik oleh pemerintah dalam bentuk kebutuhan dasar. Penyerapan anggaran merupakan salah satu tolok ukur kinerja pemerintah dalam menggerakkan roda perekonomian. Anggaran pendapatan dan belanja daerah memiliki pengaruh yang cukup signifikan dalam mendorong pertumbuhan ekonomi daerah apabila terserap secara maksimal. Penyerapan anggaran terkait pengadaan barang/jasa pada umumnya lambat bahkan realisasinya seringkali menumpuk diakhir tahun karena berbagai permasalahan yang dihadapi baik dari aspek administrasi maupun dari aspek teknis. Penelitian ini bertujuan untuk menguji pengaruh komitmen manajemen, lingkungan birokrasi, kompetensi sumber daya manusia, dan penerapan e-procurement terhadap penyerapan anggaran terkait pengadaan barang/jasa. Metode penelitian ini adalah kuantitatif dengan regresi berganda. Sampel penelitian adalah 63 orang yang menduduki jabatan di bidang yang berkaitan dengan anggaran dan pengelola pengadaan barang/jasa, diantaranya adalah pejabat pembuat komitmen, pejabat pelaksana teknis kegiatan, pejabat penandatangan surat perintah membayar, kelompok kerja pengadaan dan bendahara pengeluaran pada 14 SKPD Pemerintah Kabupaten Bolaang Mongondow Selatan. Hasil penelitian menunjukkan bahwa komitmen manajemen, lingkungan birokrasi, dan penerapan e-procurement berpengaruh positif dan signifikan terhadap penyerapan anggaran terkait pengadaan barang/jasa. Kompetensi sumber daya manusia tidak berpengaruh terhadap penyerapan anggaran terkait pengadaan barang/jasa. Implikasi praktis dari penelitian ini adalah untuk memberi masukan kepada pengambil kebijakan pada pemerintah daerah untuk lebih mengoptimalkan kompetensi sumber daya manusia dalam rangka peningkatan penyerapan anggaran.

Kata kunci: Penyerapan Anggaran, Komitmen Manajemen, Lingkungan Birokrasi, Kompetensi Sumber Daya Manusia, e-Procurement. 


\section{Pendahuluan}

Setiap tahun pemerintah pusat dan pemerintah daerah membuat rencana keuangan tahunan yang dituangkan dalam Anggaran Pendapatan dan Belanja Negara (APBN) untuk pemerintah pusat dan Anggaran Pendapatan dan Belanja Daerah (APBD) untuk pemerintah daerah dimana anggaran belanja khususnya pengadaan barang/jasa terus meningkat. Berdasarkan data dari Indonesia Procurement Watch (IPW) lebih dari 30-40 persen anggaran belanja dialokasikan untuk pengadaan barang/jasa. Dengan jumlah yang terus naik tersebut sebaiknya pemerintah memaksimalkan penggunaannya sehingga dapat terserap pada periode satu tahun anggaran agar tidak hilang manfaat belanjanya yang akhirnya berdampak pada pertumbuhan ekonomi dan pelayanan publik dapat tercapai secara maksimal (Juliani, 2014).

Pelaksanaan belanja modal oleh pemerintah bertujuan untuk meningkatkan pelayanan kepada publik dalam memenuhi kebutuhan dasar masyarakat seperti kesehatan, pendidikan, air bersih, dan transportasi, serta infrastruktur dan fasilitas umum lainnya. Belanja modal tersebut terstruktur dalam APBD sebagai pengeluaran pemerintah sehingga menjadi cerminan dukungan pemerintah dalam pembangunan untuk kesejahteraan masyarakat. Indonesia merupakan negara yang sedang meningkatkan pembangunan, oleh karenanya peran pemerintah sangat dibutuhkan sehingga dapat mendorong penguatan dan percepatan bagi pergerakan ekonomi. Upaya pemerintah ini direalisasikan dalam bentuk pencapaian pengelolaan potensi-potensi daerah dan sumber daya manusia yang memberi dampak bagi masyarakat. Hal tersebut jika dilakukan secara efektif dan efisien, maka tujuan penyelenggaraan pemerintahan akan terlaksana dengan baik. Akan tetapi pada kenyataannya, peningkatan kesejahteraan masyarakat belum memperlihatkan peningkatan oleh karena masih banyaknya hal-hal yang diharapkan oleh masyarakat yang belum terpenuhi.

Sumber-sumber penerimaan negara yang terbatas mengharuskan pemerintah menyusun prioritas kegiatan dan pengalokasian anggaran yang efektif dan efisien. Kegagalan target penyerapan anggaran mengindikasikan telah terjadinya inefisiensi dan inefektivitas pengalokasian anggaran (Carsidiawan, 2009). Belanja pemerintah menjadi pendorong utama laju pertumbuhan ekonomi. Semakin awal pelaksanaan kegiatannya, akan memberikan manfaat dan efek stimulus yang besar bagi kepentingan masyarakat. Jika pelaksanaannya mundur ke akhir tahun padahal seharusnya dilaksanakan lebih awal, maka yang dirugikan adalah masyarakat banyak karena tertunda menerima manfaat (Putu Lestari, 2017).

Penyerapan anggaran merupakan salah satu tolok ukur kinerja pemerintah dalam menggerakan roda perekonomian dan menjadi salah satu indikator evaluasi kinerja yang tertuang dalam Peraturan Menteri Keuangan PMK Nomor 249/PMK.02/2011 pasal 4 ayat 2, yaitu evaluasi kinerja atas aspek implementasi dilakukan dalam rangka menghasilkan informasi kinerja mengenai pelaksanaan kegiatan dan pencapaian keluaran. Kabupaten Bolaang Mongondow Selatan merupakan salah satu kabupaten di Indonesia yang belum memperlihatkan peningkatan realisasi anggaran khususnya pada belanja modal. Anggaran Pendapatan dan Belanja Daerah yang tersedia dari tahun ke tahun belum memperlihatkan peningkatan realisasi anggaran khususnya pada belanja modal.

Rendahnya penyerapan anggaran pada kegiatan pengadaan barang/jasa dikarenakan adanya berbagai permasalahan baik secara administrasi maupun teknis. Permasalahan tersebut antara lain proses tender yang lambat, terlambatnya Dokumen Pelaksanaan Anggaran (DPA), Sumber Daya Manusia (SDM) yang berkualitas sangat terbatas, keenganan pegawai ditunjuk untuk menjadi Pejabat Pembuat Komitmen (PPK), dan kurangnya pegawai yang memiliki sertifikat keahlian pengadaan barang/jasa merupakan hal-hal yang dapat menghambat pada pelaksanaan anggaran sehingga berdampak pada penyerapan anggaran yang tidak maksimal (Laporan Tim Warta Badan Pengawas Keuangan dan Pembangunan, 2011). Percepatan penyerapan anggaran terkait belanja pengadaan barang/jasa khususnya belanja modal patut menjadi perhatian serius pemerintah demi tercapainya pelayanan publik sebagaimana yang diamanahkan dalam Undang-Undang Nomor 25 tahun 2009 tentang Pelayanan Publik. Manfaat percepatan penyerapan anggaran belanja pengadaan barang/jasa harus dapat dinikmati oleh seluruh lapisan masyarakat dengan hasil pembangunan yang lebih cepat seperti pembangunan jalan, rumah sakit, dan juga Net Present Value dari APBD yang lebih baik (UKP4, 2012).

Komitmen manajemen yang tinggi dari pimpinan kepala SKPD sangat diperlukan dalam pelaksanaan anggaran terkait pengadaan barang/jasa agar anggaran yang tersedia dapat terserap secara maksimal. Peranan komitmen manajemen dalam meningkatkan kualitas layanan diwujudkan melalui dukungan manajemen secara simultan terhadap pelatihan, pemberdayaan, dan penghargaan (Babakus 
et al. 2003). Menurut Cooper (2006), komitmen manajemen adalah keterlibatan manajemen dalam mempertahankan perilaku karyawan untuk mencapai tujuan organisasi. Komitmen manajemen terhadap kualitas pelayananan merupakan faktor penentu perilaku karyawan dalam menciptakan pelayanan yang unggul. Oleh karena itu komitmen manajemen dapat mempengaruhi kinerja organisasi yang diwujudkan dalam bentuk pelatihan-pelatihan, pemberdayaan, dan memberikan penghargaan berupa balas jasa yang layak kepada para karyawan dan kemampuan memberikan solusi kepada karyawan (Babakus et al. 2003).

Permasalahan yang terjadi di Pemerintah Kabupaten Bolaang Mongondow Selatan dalam hal komitmen manajemen adalah rendahnya penghargaan yang diberikan terhadap karyawan (Aparatur Sipil Negara) di mana dalam hal pemberian kompensasi kegiatan belum sebanding dengan risiko pekerjaan yang ditugaskan, kurangnya kesadaran pimpinan SKPD dalam memberikan kesempatan seluas-luasnya pada karyawan untuk mengikuti bimbingan teknis pengelolaan keuangan dan pengadaan barang/jasa sehingga sumber daya manusia yang memiliki keahlian dalam pengadaan barang/jasa masih sangat terbatas. Disisi lain terdapat pegawai yang memiliki kecakapan namun tidak diberdayakan oleh pimpinan karena berbagai hal. Beberapa faktor tersebut mengakibatkan program dan kegiatan SKPD banyak menemui hambatan yang berdampak pada keterlambatan penyerapan anggaran.

Lingkungan birokrasi juga sangat mempengaruhi penyerapan anggaran terkait pengadaan barang/jasa. Birokrasi adalah skema pengorganisasian mendasar dalam melaksanakan norma dan pelayanan di negara modern, terutama yang penting di negara-negara berkembang (Campos dan Nugent, 1999). Birokrasi jika dilaksanakan secara institusional dan efektif dapat menjadi kekuatan utama dalam modernisasi kemajuan sehingga dapat menyelesaikan masalah di tengah-tengah masyarakat dan pembuat kebijakan dianggap telah melakukan hal yang wajar. Birokratisasi merupakan proses penyelenggaraan birokrasi berdasarkan peraturan dan prosedur, di mana organisasi tersebut merupakan sarana pekerjaan sosial bagi masyarakat. Birokratisasi yang terstruktur dan sistematis pada suatu institusi menggambarkan keabsahan suatu peraturan dan memastikan bahwa peraturan yang formal tersebut telah diterapkan secara efektif (Bozeman, 2015).

Menurut Sedarmayanti (2009:67), birokrasi merupakan sistem penyelenggaraan pemerintahan yang dijalankan pegawai negeri berdasarkan peraturan perundang-undangan. Birokrasi yang telah diatur dalam pemerintahan tentunya akan dipengaruhi oleh lingkungan disekitarnya baik lingkungan internal dan lingkungan eksternal. Lingkungan birokrasi yang mempengaruhi birokrasi pemerintah akan berdampak pada berjalan lancar atau tidaknya kegiatan operasional pemerintah. Aturan dan prosedur yang mengikat dan terkoordinasinya sumber daya manusia akan mempengaruhi praktik birokrasi. Oleh karena itu, lingkungan birokrasi sangat mempengaruhi penyerapan anggaran secara maksimal dan proporsional.

Persoalan birokrasi di Bolaang Mongondow Selatan sangat kompleks, dimulai dari masalah budaya birokrasi yang tidak berintegritas, banyaknya peraturan perundang-undangan yang saling tumpang tindih, struktur organisasi yang cenderung kurang berfungsi, penyelenggaraan pemerintahan yang tidak efektif dan efisien, sumber daya manusia yang tak berkompeten dan tak profesional serta kurangnya koordinasi antar pegawai dalam pelaksanaan tugas, hingga persoalan pelayanan kepada publik yang tidak responsif dan tidak bertanggung jawab merupakan parameter yang dapat menyebabkan lambannya penyerapan anggaran.

Kompetensi menurut Edison et al. (2016:145), menjelaskan bahwa untuk memenuhi unsur kompetensi, seorang pegawai harus memenuhi unsur-unsur pengetahuan, keterampilan, dan sikap dalam melaksanakan pekerjaan dengan benar. Pengawai Negeri Sipil (PNS) sebagai aparatur negara harus memiliki kompetensi sebagaimana diatur dalam Peraturan Pemerintah Nomor 101 Tahun 2000. Kompetensi menurut peraturan tersebut adalah kemampuan dan karakteristik yang dimiliki oleh Pegawai Negeri Sipil, baik berupa pengetahuan, keterampilan, dan sikap perilaku yang diperlukan dalam menunjang pelaksanaan tugas jabatannya, sehingga Pegawai Negeri Sipil tersebut dapat melaksanakan tugasnya secara profesional, efektif, dan efisien.

Masalah kompetensi sumber daya manusia hampir terjadi di semua daerah di Indonesia. Masalah-masalah tersebut dimulai dari keengganan dan ketakutan untuk menjadi panitia pengadaan oleh karena berbagai persoalan hukum yang sering menjerat pengelola pengadaan barang/jasa dan karena tidak seimbangnya resiko pekerjaan dengan imbalan yang diterima. Di samping itu, bekerja sebagai panitia merupakan pekerjaan sampingan di samping pekerjaan pokok dan rutin sehari-harinya, sehingga kurang kompeten dalam melaksanakan pengadaan barang/jasa. Hal ini beresiko terjadi keterlambatan dalam proses pengadaan barang/jasa. Permasalahan sumber daya manusia terkait erat 
dengan dorongan motivasi. Motivasi dapat berupa penghargaan dalam bentuk materi maupun inmateri. Secara materi, imbalan yang diperoleh menjadi panitia pengadaan barang/jasa kecil dibandingkan dengan resiko dan waktu yang habis tercurah (Herriyanto, 2012).

Pelaksanaan e-procurement merupakan salah satu bagian pengelolaan keuangan yang harus dilaksanakan setelah proses perencanaan anggaran selesai. Dalam proses pelaksanaan e-procurement, permasalahan yang terjadi adalah jadwal lelang yang seringkali terlalu lama karena berbagai penyebab diantaranya karena kehati-hatian pelaksana pengadaan barang/jasa dalam menyusun Harga Perkiraan Sendiri (HPS), penundaan pengumuman penyedia karena sanggahan dari penyedia lain, dokumen pengadaan yang terlalu rumit sehingga banyak peserta tidak memenuhi syarat mengikuti lelang, serta persyaratan dalam pengajuan dokumen pencairan anggaran. Hal ini mengakibatkan terjadinya inefisiensi dalam pengelolaan sumber daya ekonomi oleh pemerintah sehingga penyerapan anggaran menjadi terhambat.

Siswanto dan Rahayu (2011) menyimpulkan bahwa keterlambatan proses pengadaan barang dan jasa disebabkan oleh spesifikasi teknis barang/jasa tidak ada/tidak jelas, buruknya proses pengadaan barang/jasa satuan kerja, banyaknya sanggahan dalam proses lelang, banyaknya pengaduan Lembaga Swadaya Masyarakat mengenai pengadaan barang/jasa ke Polri dan Kejaksaan, kurangnya sosialisasi mekanisme pengadaan barang/jasa, ketidakharmonisan peraturan perundang-undangan terkait perencanaan, pelaksanaan dan pencairan anggaran, tidak seimbangnya risiko pekerjaan dengan imbalan yang diterima oleh pejabat pelaksana pengadaan, dan kehati-hatian pejabat pengadaan barang/jasa mengambil tindakan.

\section{Metode Penelitian}

Jenis penelitian yang digunakan dalam penelitian ini adalah penelitian kuantitatif dengan pendekatan asosiatif. Di dalam penelitian ini hubungan atau pengaruh yang diteliti meliputi komitmen manajemen, lingkungan birokrasi, kompetensi sumber daya manusia, dan pelaksanaan e-procurement terhadap penyerapan anggaran terkait pengadaan barang/jasa yang dikhususkan pada jenis belanja modal.

Penelitian ini dilakukan pada Pemerintah Kabupaten Bolaang Mongondow Selatan dengan sampel yang diperoleh 14 (empat belas) SKPD yang memiliki belanja modal sebagai jenis belanja yang paling rendah tingkat penyerapan anggaran. Sumber data yang digunakan adalah data primer dengan menggunakan kuesioner yang dibagikan pada responden berjumlah 67 dan kuesioner yang dapat digunakan berjumlah 63. Setelah kuesioner terkumpul dilanjutkan dengan melakukan uji validitas dan uji reliabilitas kemudian dilanjutkan dengan uji asumsi klasik.

Komitmen manajemen diukur dengan indikator komitmen mencapai target penyerapan anggaran, komitmen pimpinan terhadap dukungan pelatihan, pemberdayaan terhadap pegawai dalam pelaksanaan pengadaan barang/jasa, penghargaan atas kinerja pegawai dan kemampuan memberikan solusi terhadap permasalahan yang terdiri dari 7 (tujuh) pernyataan. Lingkungan birokrasi diukur dengan indikator koordinasi antar pegawai dan birokrasi pengadaan barang/jasa yang terdiri dari 7 (tujuh) pernyataan. Kompetensi sumber daya manusia diukur dengan indikator pengetahuan, keterampilan dan sikap yang terdiri dari 7 (tujuh) pernyataan. Pelaksanaan e-procurement diukur dengan indikator jadwal pelaksanaan pengadaan barang/jasa dan dokumen pengadaan yang terdiri dari 7 (tujuh) pernyataan. Masing-masing item pernyataan tersebut kemudian diukur dengan menggunakan skala Likert 5 point.

\section{Hasil dan Pembahasan}

Pengujian validitas dalam penelitian ini menggunakan Pearson Correlation yaitu dengan cara menghitung korelasi antara skor masing-masing butir pernyataan dengan skor total. Jika korelasi antara skor masing-masing butir pernyataan dengan skor total mempunyai tingkat signifikansi $<0,05$ maka butir pernyataan tersebut dinyatakan valid dan sebaliknya (Sugiyono, 2014). Semua item pernyataan untuk variabel komitmen manajemen, lingkungan birokrasi, kompetensi sumber daya manusia dan pelaksanaan e-procurement dinyatakan valid dengan nilai signifikansi $<0,05$. Hal ini berarti semua item pernyataan yang digunakan dalam penelitian ini mampu mengungkapkan semua variabel yang diukur pada kuesioner tersebut.

Uji reliabilitas dilakukan menggunakan teknik Cronbach Alpha. Jika nilai koefisien alpha > 0,60 maka disimpulkan bahwa instrumen penelitian tersebut handal atau reliable (Ghozali, 2011). Berdasarkan uji reliabilitas menunjukkan nilai Cronbach's Alpha untuk variabel komitmen manajemen sebesar 0,737 , lingkungan birokrasi sebesar 0,721 ; kompetensi sumber daya manusia sebesar 0,703 ; 
pelaksanaan e-procurement sebesar 0,687 dan penyerapan anggaran terkait pengadaan barang/jasa sebesar 0,768. Dengan demikian pengukuran kuesioner ini reliable karena memiliki nilai Cronbach's Alpha $>0,60$.

Uji normalitas dilakukan untuk mengetahui data berdistribusi normal. Uji normalitas dalam penelitian ini dengan menggunakan grafik P-Plot SPSS dan uji normalitas Kolmogorov-Smirnov. Untuk uji pola penyebaran $P$-Plot, jika titik-titik data menyebar disekitar garis diagonal dan penyebaran titik-titik data searah mengikuti garis diagonal maka dapat dikatakan data berdistribusi normal. Sedangkan pada uji normalitas Kolmogorov-Smirnov akan dilihat nilai signifikansinya apabila lebih dari 0,05 maka data tersebut berdistribusi normal (Ghozali, 2011). Berdasarkan uji normalitas dengan grafik P-Plot SPSS, didapatkan bahwa titik data menyebar di sekitar garis diagonal dan penyebaran titik-titik data searah mengikuti garis diagonal. Berdasarkan uji normalitas KolmogorovSmirnov dilihat bahwa nilai asymp.sig (2-tailed) atau signifikansi sebesar 0,982 lebih besar dari alpha $(\alpha=0,05)$ sehingga dapat disimpulkan bahwa data yang diuji berdistribusi normal. Dengan demikian model regresi telah memenuhi uji asumsi normalitas.

Uji multikolinieritas dilakukan untuk melihat apakah pada model regresi ditemukan adanya korelasi antara variabel independen. Cara mendeteksinya adalah dengan melihat nilai tolerance dan nilai Variance Inflation Factor (VIF). Jika nilai VIF $<10$ dan tolerance $>0,1$ maka variabel independen terbebas dari persoalan multikolinieritas (Ghozali, 2013). Hasil uji SPSS menunjukkan bahwa semua nilai tolerance $>0,1$ dan nilai $\mathrm{VIF}<10$.

Tabel 1. Hasil Regresi Linear Berganda

\begin{tabular}{|c|c|c|c|c|c|}
\hline \multicolumn{6}{|c|}{ Coefficients $^{\mathrm{a}}$} \\
\hline \multirow[t]{2}{*}{ Model } & \multicolumn{2}{|c|}{$\begin{array}{c}\text { Unstandardized } \\
\text { Coefficients }\end{array}$} & $\begin{array}{l}\text { Standardized } \\
\text { Coefficients }\end{array}$ & $\mathrm{t}$ & Sig. \\
\hline & $\mathrm{B}$ & Std. Error & Beta & & \\
\hline (Constant) & 2.649 & 5.004 & & .529 & .599 \\
\hline Komitmen Manajemen & .266 & .109 & .279 & 2.438 & .018 \\
\hline Lingkungan Birokrasi & .284 & .107 & .291 & 2.655 & .010 \\
\hline Kompetensi Sumber Daya Manusia & .119 & .095 & .140 & 1.245 & .218 \\
\hline Pelaksanaan e-procurement & .269 & .120 & .255 & 2.248 & .028 \\
\hline
\end{tabular}

Uji heteroskedastisitas bertujuan untuk mengetahui apakah dalam sebuah model regresi terjadi ketidaksamaan variance dari residual suatu pengamatan ke pengamatan lain. Heteroskedastisitas ditandai dengan adanya pola tertentu pada grafik scatterplot. Jika titik-titik yang ada membentuk suatu pola tertentu yang teratur, maka terjadi heteroskedastisitas. Namun jika tidak ada pola yang jelas, yaitu serat titik-titik menyebar di atas dan di bawah angka 0 pada sumbu Y, maka tidak terjadi heteroskedastisitas. Selain itu, heteroskedastisitas dapat diketahui melalui uji glejser. Jika probabilitas masing-masing variabel independen > 0,05, maka tidak terjadi heteroskedastisitas (Ghozali, 2013). Hasil uji menunjukkan bahwa pada scatterplot, titik-titik yang ada tidak membentuk sebuah pola namun menyebar, sehingga dapat disimpulkan bahwa dalam penelitian tidak terjadi heteroskedastisitas. Selain itu melalui uji glejser nilai signifikansi masing-masing variabel $>0,05$, maka dapat disimpulkan tidak terjadi heteroskedastisitas.

Hasil pengujian asumsi klasik menunjukkan bahwa model regresi yang dipakai telah memenuhi asumsi klasik sehingga dapat dilanjutkan dengan analisis regresi berganda. Model regresi berganda dalam penelitian ini adalah untuk menguji pengaruh komitmen manajemen $\left(\mathrm{X}_{1}\right)$, lingkungan birokrasi $\left(\mathrm{X}_{2}\right)$, kompetensi sumber daya manusia $\left(\mathrm{X}_{3}\right)$, pelaksanaan e-procurement $\left(\mathrm{X}_{4}\right)$ dan terhadap penyerapan angggaran terkait pengadaan barang/jasa (Y).

Pengujian hipotesis secara parsial dilakukan melalui uji t untuk mengetahui besarnya pengaruh masing-masing variabel independen secara individual terhadap variabel dependen. Uji t juga dilakukan dengan membandingkan nilai $t_{\text {hitung }}$ dengan nilai $t_{\text {tabel }}$. Nilai $t_{\text {hitung }}$ diperoleh dari hasil perhitungan SPSS sedangkan $\mathrm{t}_{\text {tabel }}$ diperoleh dari tabel distribusi t dicari pada $\alpha=5 \%: 2=2,5 \%$ (uji 2 sisi) dengan derajat kebebasan (df) n-k-1 atau 63-4-1 $=58$. Dengan pengujian 2 sisi (signifikansi $=0,025$ ) hasil diperoleh untuk $\mathrm{t}_{\text {tabel }}$ sebesar 2.002 . 
Pengaruh komitmen manajemen terhadap penyerapan anggaran terkait pengadaan barang/jasa, $t_{\text {hitung }}=2,438>t_{\text {tabel }}=2,002$ dan signifikansi dari variabel komitmen manajemen adalah sebesar 0,018 < 0,05. Hal ini menunjukkan bahwa $\mathrm{Ha}_{1}$ diterima dan $\mathrm{Ho}_{1}$ ditolak, sehingga terbukti bahwa komitmen manajemen berpengaruh positif dan signifikan terhadap penyerapan anggaran terkait pengadaan barang/jasa.

Pengaruh lingkungan birokrasi terhadap penyerapan anggaran terkait pengadaan barang/jasa, $t_{\text {hitung }}=2,655>t_{\text {tabel }}=2,002$ dan signifikansi dari variabel lingkungan birokrasi adalah sebesar $0,010<$ 0,05 . Hal ini menunjukkan bahwa $\mathrm{Ha}_{2}$ diterima dan $\mathrm{Ho}_{2}$ ditolak, sehingga terbukti bahwa lingkungan birokrasi berpengaruh positif dan signifikan terhadap penyerapan anggaran terkait pengadaan barang/jasa.

Pengaruh kompetensi sumber daya manusia terhadap penyerapan anggaran terkait pengadaan barang/jasa, $\mathrm{t}_{\text {hitung }}=1,245<\mathrm{t}_{\text {tabel }}=2,002$ dan signifikansi dari variabel pengadaan barang jasa adalah sebesar 0,218>0,05. Hal ini menunjukkan bahwa $\mathrm{Ha}_{3}$ ditolak dan $\mathrm{Ho}_{3}$ diterima, sehingga dinyatakan bahwa kompetensi sumber daya manusia tidak berpengaruh terhadap penyerapan anggaran terkait pengadaan barang/jasa.

Pengaruh pelaksanaan e-procurement terhadap penyerapan anggaran terkait pengadaan barang/jasa, $t_{\text {hitung }}=2,248>t_{\text {tabel }}=2,002$ signifikansi dari variabel pelaksanaan e-procurement adalah sebesar $0,028<0,05$. Hal ini menunjukkan bahwa $\mathrm{Ha}_{4}$ diterima dan $\mathrm{Ho}_{4}$ ditolak, sehingga terbukti bahwa pelaksanaan e-procurement berpengaruh positif dan signifikan terhadap penyerapan anggaran terkait pengadaan barang/jasa.

Untuk regresi dengan lebih dari dua variabel bebas digunakan adjusted $R^{2}$ sebagai koefisien determinasi. Jika nilai adjusted $R^{2}$ sama dengan 0 , maka variasi variabel independen yang digunakan dalam model tidak menjelaskan sedikitpun variasi variabel dependen. Sebaliknya adjusted $R^{2}$ sama dengan 1 , maka variasi variabel independen yang digunakan dalam model menjelaskan $100 \%$ variasi variabel dependen. Nilai adjusted $\mathrm{R}^{2}$ adalah 0,321 yang artinya penyerapan anggaran sebesar $32,1 \%$ dipengaruhi oleh komitmen manajemen, lingkungan birokrasi, kompetensi sumber daya manusia dan pelaksanaan e-procurement sedangkan sisanya $67,9 \%$ dipengaruhi oleh faktor lain di luar penelitian ini.

\section{Pengaruh Komitmen Manajemen terhadap Penyerapan Anggaran Belanja Modal}

Hasil pengujian hipotesis pertama menunjukkan bahwa variabel komitmen manajemen berpengaruh positif dan signifikan terhadap penyerapan anggaran belanja modal Pemerintah Kabupaten Bolaang Mongondow Selatan. Nilai koefisien regresi komitmen manajemen menunjukkan bahwa terdapat komitmen manajemen yang tinggi pada SKPD untuk mencapai percepatan penyerapan anggaran. Dukungan kepala SKPD diperlukan untuk perbaikan dalam pelaksanaan anggaran terkait pengadaan barang/jasa khususnya belanja modal pada instansi yang dipimpinnya. Komitmen yang tinggi dari kepala SKPD sangat mempengaruhi penyerapan anggaran.

Hasil pengujian ini sesuai dengan konsep komitmen manajemen menurut (Babakus et al. 2003), yang menyatakan bahwa peranan komitmen manajemen dalam meningkatkan kualitas layanan diwujudkan melalui dukungan manajemen secara simultan terhadap pelatihan, pemberdayaan dan penghargaan, pendekatan-pendekatan positif terhadap kebutuhan sumber daya dan berkontribusi dalam membantu mengatasi kekurangan-kekurangan akan meningkatkan pelaksanaan suatu tugas atau proyek yang sedang dikerjakan. Demikian juga dengan Cooper (2006 yang menyatakan bahwa komitmen manajemen adalah keterlibatan manajemen dalam mempertahankan perilaku karyawan untuk mencapai tujuan organisasi.

Komitmen manajemen merupakan peran kepala SKPD selaku pengguna anggaran dengan berbagai upaya untuk mencapai target penyerapan anggaran yang maksimal. Dengan komitmen manajemen yang sungguh-sungguh terhadap kualitas layanan maka dapat memperbaiki kegagalan layanan yang terjadi dan akhirnya dapat meningkatkan kinerja perbaikan layanan. Komitmen manajemen itu adalah prasyarat penting bagi keberhasilan manajemen untuk peningkatan mutu. Selain itu merupakan faktor pendorong untuk memotivasi karyawan agar berupaya meningkatkan kualitas proses yang berkesinambungan. Selain itu komitmen manajemen juga harus terlibat langsung dan mempertahankan kinerja karyawan untuk membantu mencapai tujuan. Dikatakan dalam Babakus et al. (2003), bahwa adanya kebijakan penghargaan yang tepat dalam suatu perusahaan tidak hanya penting dalam mendorong karyawan untuk memberikan pelayanan yang baik tetapi juga memotivasi mereka untuk menangani keluhan pelanggan dengan baik. 
Lingkup anggaran menjadi relevan dan penting di lingkungan pemerintah daerah. Hal ini terkait dengan pentingnya anggaran dan dampaknya terhadap kinerja pemerintah, sehubungan dengan fungsi pemerintah dalam memberikan pelayanan kepada masyarakat. Anggaran sektor publik merupakan dokumen/kontrak politik antara pemerintah dengan DPRD untuk masa yang akan datang (Mardiasmo, 2009). Selanjutnya, DPRD akan mengawasi kinerja pemerintah melalui anggaran. Bentuk pengawasan ini sesuai dengan agency theory di mana pemerintah sebagai agent dan DPRD sebagai principal. Selanjutnya dilingkup SKPD, hubungan principal dan agent terjadi di mana bawahan di SKPD bertindak sebagai agent berdasarkan pendelegasian dari principal sebagai pemberi amanah dalam hal ini kepala SKPD.

Komitmen manajemen di Pemerintah Kabupaten Bolaang Mongondow Selatan terhadap penyerapan anggaran sangat dibutuhkan karena akan sangat mempengaruhi maksimal atau tidaknya penyerapan anggaran. Kepala SKPD memberikan dukungan secara nyata terhadap kinerja bawahannya untuk mencapai target penyerapan anggaran.

Hasil penelitian ini mendukung penelitian Juliani (2014) yang berjudul pengaruh faktor-faktor kontekstual terhadap persepsian penyerapan anggaran, memberikan hasil bahwa komitmen manajemen berpengaruh positif terhadap penyerapan anggaran.

\section{Pengaruh Lingkungan Birokrasi terhadap Penyerapan Anggaran Belanja Modal}

Hasil pengujian hipotesis kedua menunjukkan bahwa variabel lingkungan birokrasi berpengaruh positif dan signifikan terhadap penyerapan anggaran belanja modal. Nilai koefisien regresi lingkungan birokrasi menunjukkan bahwa kondisi lingkungan birokrasi yang baik di SKPD sangat mempengaruhi percepatan penyerapan anggaran.

Konsep yang yang dikemukakan oleh Eisenstadt (1959) menyatakan bahwa birokrasi merupakan alat atau mekanisme yang dibuat untuk kesuksesan dan efisiensi suatu pelaksanaan kegiatan dalam mencapai tujuan atau sasaran tertentu. Kondisi atau keadaan birokrasi yang ada pada pemerintah daerah akan sangat mempengaruhi berjalan lancar atau tidaknya kegiatan mereka. Lingkungan birokrasi yang baik akan membuat pelaksanaan kegiatan operasional menjadi lancar. Namun jika lingkungan birokrasi tidak mendukung kegiatan organisasi maka akan menghambat kinerja organisasi (Eisenstadt, 1959). Oleh karena itu, lingkungan birokrasi dapat mempengaruhi penyerapan anggaran.

Hasil pengujian ini sejalan dengan teori goal-seting yang dikemukakan oleh Gibson et al. (1985), yang menyatakan bahwa goal-setting adalah proses yang melibatkan atasan dan bawahan secara bersama-sama dalam penentuan atau penetapan sasaran atau tujuan-tujuan kerja yang akan dilaksanakan. Sasaran atau target bisa ditambah dengan memberi penjelasan atau informasi kepada tenaga kerja bagaimana mengerjakan tugas tersebut, serta mengapa sasaran atau tujuan tersebut penting dilaksanakan. Teori penetapan tujuan (goal-setting) yang dikembangkan oleh Locke (1984) yang menjelaskan hubungan antara tujuan yang ditetapkan dengan prestasi kerja (kinerja). Dari pendapat para ahli di atas disimpulkan bahwa penetapan target berorientasi hasil. Manajemen yang berorientasi ini dianggap lebih baik karena lebih menekankan pencapaian hasil sehingga manajemen akan mengarah pada tenaga kerja supaya mengerti bagaimana mereka bekerja.

Lingkungan birokrasi merupakan keadaan atau kondisi yang ada di dalam SKPD untuk mendukung terlaksananya tujuan organisasi. Lingkungan birokrasi mempengaruhi penyerapan anggaran karena adanya dukungan dan lingkungan yang kondusif serta keadaan di SKPD yang dapat mendukung tercapainya penyerapan anggaran menjadi lebih baik. Koordinasi dan kerjasama sangat dibutuhkan oleh seluruh pegawai agar dapat mencapai penyerapan anggaran yang maksimal (Juliani, 2014). Semakin baik koordinasi dalam implementasinya antara penerima amanah (agent) dan pemberi amanah (principal) akan semakin memudahkan pemegang amanah (agent) dalam melaksanakan program dan kegiatan yang ada di satuan kerja sehingga diharapkan serapan anggaran dapat lebih cepat dilakukan.

Lingkungan birokrasi seperti adanya arahan yang diberikan atasan dilaksanakan dengan baik oleh bawahan, koordinasi yang terjalin dengan baik, pegawai yang terlibat dalam proses pengadaan barang/jasa memadai, serta pemahaman terhadap peraturan perundang-undangan yang berlaku sangat dibutuhkan oleh Pemerintah Kabupaten Bolaang Mongondow Selatan untuk percepatan penyerapan anggaran.

Hasil penelitian ini mendukung penelitian Juliani (2014) yang berjudul pengaruh faktor-faktor kontekstual terhadap persepsian penyerapan anggaran, memberikan hasil bahwa lingkungan birokrasi berpengaruh positif terhadap penyerapan anggaran. 


\section{Pengaruh Kompetensi Sumber Daya Manusia terhadap Penyerapan Anggaran Belanja Modal}

Hasil pengujian hipotesis ketiga menunjukkan bahwa variabel kompetensi sumber daya manusia tidak berpengaruh terhadap penyerapan anggaran belanja modal. Nilai koefisien regresi variabel kompetensi sumber daya manusia menunjukkan bahwa kompetensi sumber daya manusia tidak berpengaruh terhadap percepatan penyerapan anggaran. Dengan demikian hipotesis ketiga ditolak karena secara empirik tidak terbukti.

Penelitian ini berpendapat bahwa diperolehnya hasil yang berlawanan dengan hipotesis dapat dijelaskan melalui beberapa permasalahan seperti dalam melakukan pengelolaan pengadaan barang/jasa para pegawai masih diberi tanggung jawab yang lain atau rangkap tugas untuk melakukan pelaksanaan pengelolaan pengadaan barang/jasa ataupun tugas tugas administrasi lainya, sehingga sering terjadi penumpukan tugas yang berdampak pada kinerja untuk melaksanakan penyerapan anggaran yang menjadi tidak efektif untuk diselesaikan sesuai dengan waktu yang ditentukan. Beban kerja berlebih dapat menyebabkan kompetensi sumber daya manusia akan menurun karena apabila beban kerja yang diberikan melebihi kemampuan pegawai dapat mempengaruhi kinerja dalam hal penyerapan anggaran terkait pengadaan barang/jasa.

Hasil temuan dalam penelitian ini dapat dijelaskan dengan teori Manajemen Sumber Daya Manusia yang dikemukakan oleh Winaya (1989). Winaya (1989) mengemukakan bahwa adanya dampak negatif dari kelebihan beban kerja yang tidak sesuai dengan kemampuan tenaga kerja dapat menimbulkan dampak negatif bagi pegawai. Dampak negatif tersebut dimana menyebabkan beban kerja yang terlalu berat tidak diimbangi dengan kemampuan tenaga kerja, kelebihan beban kerja akan mengakibatkan menurunnya kualitas kerja karena akibat dari kelelahan fisik dan turunnya konsentrasi, pengawasan diri, akurasi kerja sehingga hasil kerja tidak sesuai dengan standar.

Penelitian yang dilakukan oleh Indriantoro (2000) menyatakan bahwa peningkatan kompleksitas dalam suatu tugas atau sistem akan menurunkan tingkat keberhasilan tugas tersebut. Terkait dengan pelaksanaan anggaran, bila semakin tinggi kompleksitas pekerjaan dapat menyebabkan pegawai pengelola anggaran dan pengelola barang/jasa akan berperilaku disfungsional yang dapat menyebabkan penurunan kinerja dalam melaksanakan tugasnya.

Penelitian ini sejalan dengan penelitian yang dilakukan oleh Purtanto (2015) yang menyatakan bahwa kompetensi sumber daya manusia tidak berpengaruh positif terhadap penyerapan anggaran, namun tidak sejalan dengan penelitian Herriyanto (2012) yang menyatakan bahwa kompetensi sumber daya manusia berpengaruh dalam percepatan penyerapan anggaran.

\section{Pengaruh Pelaksanaan e-Procurement terhadap Penyerapan Anggaran Belanja Modal}

Hasil pengujian hipotesis keempat menunjukkan bahwa variabel pelaksanaan e-procurement berpengaruh positif dan signifikan terhadap penyerapan anggaran belanja modal. Nilai koefisien regresi variabel pelaksanaan e-procurement menunjukkan bahwa semakin baik pelaksanaan $e$ procurement di SKPD sangat mempengaruhi percepatan penyerapan anggaran.

Electronic Procurement (e-procurement) merupakan sistem baru yang di bangun oleh pemerintah untuk mempercepat proses pengadaan barang dan jasa. Selain bertujuan untuk percepatan penyerapan anggaran, e-procurement diharapkan dapat memberikan manfaat positif dan mampu mewujudkan pengadaan barang dan jasa yang menerapkan prinsip good governance serta mampu menghemat anggaran maupun waktu yang digunakan. Peraturan Presiden Nomor 70 Tahun 2012 tentang perubahan kedua Peraturan Presiden Nomor 54 Tahun 2010 tentang Pengadaan Barang dan Jasa dijelaskan bahwa pengadaan barang/jasa adalah kegiatan untuk memperoleh barang/jasa oleh Kementerian/Lembaga/Satuan Kerja Perangkat Daerah/Institusi (K/L/D/I) yang prosesnya dimulai dari perencanaan kebutuhan sampai diselesaikannya seluruh kegiatan untuk memperoleh barang/jasa.

Teori agensi berlaku dalam pelaksanaan e-procurement (Yukins, 2010), yang menyatakan bahwa dalam pelaksanaan e-procurement sering terjadi proses politik yang menggambarkan hubungan antara principal-agent, dimana pada pendekatan teori principal-agent menggambarkan hubungan para stakeholder's dalam implementasi e-procurement. Principal menurut Khan dan Hildreth (2002), adalah siapa yang mengalokasikan sumber-sumber pemerintahan dan agent adalah siapa yang diserahi sumber-sumber pemerintahan tersebut, selanjutnya Khan dan Hildreth (2002), menjelaskan bahwa dalam hubungan ini principal memiliki sebuah kesepakatan dengan agent untuk melayani masyarakat.

Dalam implementasi e-procurement, legislatif dan eksekutif adalah biasa disebut dengan principal, karena merekalah yang memberikan sumber-sumber pengadaan (Yukins, 2010). Sementara manajemen e-procurement dan penyedia barang dan jasa disebut dengan agent, karena merekalah 
yang diserahkan sumber-sumber pengadaan dan berkewajiban untuk melayani masyarakat. Dengan pendekatan principal-agent dapat memahami penyebab dan konsekuensi di mana principal harus memilih dan memonitoring agent atas kewenangan yang telah didelegasikan (Che, 2007). Selanjutnya Che (2007) menjelaskan bahwa konsep principal-agent mengandung tiga konsep yaitu delegasi, pilihan, dan monitoring.

Pelaksanaan e-procurement merupakan salah satu bagian pengelolaan keuangan yang harus dilaksanakan setelah proses perencanaan anggaran selesai. Dalam proses palaksanaan e-procurement, masalah yang sering terjadi adalah keterlambatan proses pengadaan barang/jasa yang disebabkan oleh spesifikasi teknis barang/jasa tidak ada/tidak jelas, buruknya proses pengadaan barang/jasa satuan kerja, banyaknya sanggahan dalam proses lelang, banyaknya pengaduan Lembaga Swadaya Masyarakat (LSM) mengenai pengadaan barang/jasa ke Kepolisian dan Kejaksaan, kurangnya sosialisasi mekanisme pengadaan barang/jasa, ketidakharmonisan peraturan perundang-undangan terkait perencanaan, pelaksanaan dan pencairan anggaran, tidak seimbangnya risiko pekerjaan dengan imbalan yang diterima oleh pejabat pelaksana pengadaan dan kehati-hatian pejabat pengadaan barang/jasa mengambil tindakan (Siswanto dan Rahayu, 2011). Adanya pejabat pengelola keuangan yang sering mutasi juga turut memperburuk penyerapan anggaran. Seringnya pejabat pengelola keuangan yang mutasi mempengaruhi terhambatnya penyerapan anggaran karena setiap adanya pergantian pejabat pengelola keuangan, membutuhkan penetapan pejabat pengelola keuangan yang baru.

Pemerintah Kabupaten Bolaang Mongondow Selatan dalam pelaksanaan anggaran telah dilakukan berdasarkan Peraturan Presiden Nomor 70 Tahun 2012. Proses pengadaan barang/jasa dilaksanakan dengan menggunakan e-procurement agar pengadaan barang/jasa menjadi transparan, efisien dan efektif. Dalam pelaksanaannya, sistem e-procurement di Kabupaten Bolaang Mongondow Selatan banyak menemui tantangan dan hambatan yang dihadapi oleh Pemerintah Kabupaten Bolaang Mongondow Selatan selain faktor administrasi. Masalah infrastruktur jaringan internet sebagai syarat utama dalam e-procurement yang belum memadai. Selajutnya persoalan keterbatasan daya listrik yang menganggu proses tender karena setiap hari dilakukan pemadaman listrik secara bergilir.

Hasil penelitian ini mendukung penelitian Siswanto dan Rahayu (2011) yang berjudul faktorfaktor penyebab pendahnya penyerapan belanja Kementerian/Lembaga TA 2010 dan penelitian Taufik (2016) yang berjudul pengaruh penerapan e-procurement dan kompetensi pejabat pembuat komitmen terhadap pelaksanaan pengadaan barang dan jasa dan implikasinya terhadap penyerapan belanja modal (Studi pada Satuan Kerja Lingkup Pembayaran Kantor Pelayanan Perbendaharaan Negara Banda Aceh).

\section{Kesimpulan dan Saran}

Berdasarkan hasil penelitian yang diperoleh, maka dapat disimpulkan bahwa komitmen manajemen, lingkungan birokrasi dan pelaksanaan e-procurement berpengaruh positif dan signifikan terhadap penyerapan anggaran terkait pengadaan barang/jasa pada Pemerintah Kabupaten Bolaang Mongondow Selatan. Sedangkan kompetensi sumber daya manusia tidak berpengaruh terhadap penyerapan anggaran terkait Pengadaan Barang/Jasa pada Pemerintah Kabupaten Bolaang Mongondow Selatan.

Saran untuk Pemerintah Kabupaten Bolaang Mongondow Selatan dalam upaya untuk meningkatkan penyerapan anggaran diharapkan Pemerintah Daerah memberikan perhatian yang serius terhadap permasalahan penyerapan anggaran, dengan cara terus memperbaiki kinerja terutama dalam bidang pengelolaan keuangan daerah. Meningkatkan komitmen pimpinan SKPD dengan cara mendukung pelatihan/bimbingan teknis bagi para Aparatur Sipil Negara (ASN), memberdayakan para pegawai yang terlibat dalam proses penyerapan anggaran. Menciptakan lingkungan birokrasi yang baik dengan cara menjalin koordinasi yang baik antar pegawai. Memperbaiki infrastruktur teknologi informasi sehingga dapat meningkatkan akses internet guna mendukung pelaksanaan penerapan $e$ procurement.

1. Melakukan proses pengadaan barang/jasa terutama belanja modal sejak awal tahun anggaran mengingat waktu pelaksaannya memakan waktu yang cukup panjang sehingga realisasi anggaran dapat terserap maksimal dan tidak menumpuk diakhir tahun anggaran.

2. Untuk meminimalisasi permasalahan pejabat/pegawai pengelola keuangan sering mengalami mutasi, maka sebaiknya pola mutasi bagi pengelola keuangan diatur sedemikian rupa sehingga tidak menghambat percepatan penyerapan anggaran, misalnya mutasi dilakukan setelah tahun anggaran berakhir dimana semua kegiatan selesai dipertanggungjawabkan. 


\section{Daftar Pustaka}

Babakus, E., U. Yavas, O. M., Karatepe, dan T. Avci. 2003. The Effect of Management Commitment to Service Quality on Employees, Affective and Performance Outcomes. Journal of the Academy of Marketing Science.

Bozeman, Barry. 2015. Bureaucratization in Academic Research Policy: Perspectives from Red Tape Theory. Center for Organization Research and Design Arizona State University.

Campos, Nauro dan Nugent Jeffrey. 1999. Development Performance and the Institution of Governance: Evidence from East Asia and Latin America, World Development, 27, 439-452.

Carsidiawan. Didi, 2009. Mengungkap penyebab lambatnya penyerapan anggaran belanja pemerintah. Buletin anggaran dan perbendaharaan [buletin "A\&P"].

Che, Tafor Princewill. 2007. Public Accountability in Cameroon: A Case Study of Public Procurement Management. Finland. University of Jyvaskyla.

Cooper, M. D. 2006. Exploratory Analyses of the Effects of Managerial Support and Feedback Consequences on Behavioral Safety Maintenance, Journal of Organizational Behavior Management 26 (3).

Edison, Emron., Yohny Anwar., dan Imas Komariyah. 2016. Manajemen Sumber Daya Manusia, Bandung: CV. Alfabeta.

Eisenstadt, S. N. 1959. Bureaucracy, Bureaucratization, and Debureaucratization. Administrative Science Quarterly, 302-320.

Ghozali, Imam, 2011, Aplikasi Analisis Multivariate Dengan Program SPSS. Semarang: Badan Penerbit Universitas Diponegoro. Semarang.

Ghozali, Imam, 2013. Aplikasi Analisis Multivariat dengan Program IBM SPSS 21. Edisi 7, Penerbit Universitas Diponegoro. Semarang.

Gibson, J.L., Ivancevich, J.M. and Donelly, Jr., J.H. 1985. Organizations. $5^{\text {th }}$ Edition. Business Publication, Inc.

Herriyanto, Hendris, 2012. Faktor-faktor Yang Mempengaruhi Keterlambatan Penyerapan Anggaran Belanja Pada Satuan Kerja Kementerian/Lembaga di Wilayah Jakarta. Tesis. Jakarta: Universitas Indonesia.

Indonesia Procurement Watch (IPW). 2011. Laporan Survei Jejak Suap Dalam Pengadaan Barang/Jasa Pemerintah.

Tersedia

http://www.iprocwatch.org/images/stories/data/laporan_survei_suap_pbjp.pdf

Indriantoro, N. (2000). Pengaruh partisipasi terhadap kepuasan pemakai dalam pengembangan sistem informasi dengan kompleksitas tugas, kompleksitas sistem, dan pengaruh pemakai sebagai moderating variabel. Jurnal Riset Akuntansi Indonesia, 3(2), 119-133

.Juliani. Dian. 2014. Pengaruh Faktor-faktor Konstektual Terhadap Persepsian Penyerapan Anggaran Terkait Pengadaan Barang/Jasa. Tesis-Jurnal. Yogyakarta: Universitas Gadjah Mada.

Khan, Aman., dan Hildreth, W. Bartley. 2002. Budget Theory in the Public Sector, Library of Congress Cataloging-in-Publication Data.

Laporan Tim Warta BPKP. 2011. Problematika Penyerapan Anggaran di Daerah. Tersedia di http://swamandiri.wordpress.com/ 2011/02 /12/ problematikapenyerapan-anggaran-di-daerah/.

Lestari, Ni Luh Putu Dewi. 2017. Kemampuan Komitmen Organisasi Memoderasi Pengaruh Perencanaan Anggaran dan Kompetensi SDM Pada Penyerapan Anggaran Pemerintah Kabupaten Tabanan. Denpasar: Universitas Udayana.

Locke. E. A.. Saari L. M.. Shaw E. N. and Lathan. G. P. 1984. Goal Setting and Task Performance: 1969-1980. Psychological Bulletin. Vol. 90.

Mardiasmo. 2009. Akuntansi Sektor Publik. Yogyakarta: ANDI.

Peraturan Menteri Keuangan Republik Indonesia Nomor 249/PMK.02/2011 Tentang Pengukuran dan Evaluasi Kinerja atas Pelaksanaan Rencana Kerja dan Anggaran Kementerian Negara/Lembaga.

Peraturan Pemerintah Nomor 101 Tahun 2000 Tentang Diklat Jabatan Pegawai Negeri Sipil.

Purtanto, 2016, Faktor-Faktor Yang Mempengaruhi Penyerapan Anggaran Belanja Pemerintah Daerah: Pengadaan Barang/Jasa. Tesis-Jurnal. Surakarta: Universitas Sebelas Maret.

Sedarmayanti. 2009. Membangun dan Mengembangkan Kepemimpinan serta Meningkatkan Kinerja untuk Meraih Keberhasilan. Cetakan Pertama. Bandung: PT. Refika Aditama. 
Siswanto dan Rahayu. 2011. Faktor-faktor Penyebab Rendahnya Penyerapan Belanja Kementerian/Lembaga TA 2010. Jurnal. Badan Kebijakan Fiskal. Kementerian Keuangan.

Sugiyono. 2014. Metode Penelitian Pendidikan (Pendekatan Kuantitatif, Kualitatif, dan R\&D). Bandung : Alfabeta.

Taufik, Muhamad. 2016. Pengaruh Penerapan e-Procurement dan Kompetensi Pejabat Pembuat Komitmen Terhadap Pelaksanaan Pengadaan Barang dan Jasa dan Implikasinya Terhadap Penyerapan Belanja Modal (Studi pada Satuan Kerja Lingkup Pembayaran Kantor Pelayanan Perbendaharaan Negara Banda Aceh). Tesis-Jurnal. Universitas Syiah Kuala. Banda Aceh.

Undang-Undang Republik Indonesia Nomor 25 Tahun 2004 tentang Sistem Perencanaan dan Pembangunan Nasional.

Unit Kerja Presiden Bidang Pengawasan dan Pengedalian Pembangunan (UKP4). 2012. Pengawasan Penyerapan Anggaran dan Pengendalian Kegiatan. Tersedia di http://www.ukp.go.id/informasi-publik/cat_view/27-timevaluasi-dan-percepatan-penyerapananggaran.

Winaya, Kuna. 1989. Manajemen Sumber Daya Manusia (Lanjutan). Edisi Ketiga, Fakultas Ekonomi Universitas Udayana. Denpasar.

Yukins, C.R. 2010. Assessing the World Bank's Proposed Revision of its Procurement Guidelines: The Government Contractor, 52(21):1-5. 